\title{
Causality and Cointegration Between Export, Import and Economic Growth: Evidence from Morocco
}

\author{
Aicha El Alaoui \\ Polyvalent Laboratory of Research and Development, (PLRD) BeniMellal, University Sultan My Slimane, BeniMellal, Morocco \\ Email address: \\ aicha_elalaoui@yahoo.fr \\ To cite this article: \\ Aicha El Alaoui. Causality and Cointegration Between Export, Import and Economic Growth: Evidence from Morocco. Journal of World \\ Economic Research. Vol. 4, No. 3, 2015, pp. 83-91. doi: 10.11648/j.jwer.20150403.14
}

\begin{abstract}
This article investigates the relationship between export, import and economic growth using annual time series data for the Moroccan economy over the period 1980-2013. The cointegration technique has been employed to see the long run equilibrium relationship among variables. For this end, Granger causality test based on vector error correction model (VECM) has been adopted to see both short and long run causality among the variables. The cointegration results confirm the existence of the long-run relationship among these variables. For the short-run causality, the findings suggest (i) bidirectional causality between economic growth and import, (ii) unidirectional causality that run from export to import, and (iii) no-directional causality between economic growth and export.
\end{abstract}

Keywords: Economic Growth, Export, Import, Granger Causality, Cointegration, VECM

\section{Introduction}

Since independence, Morocco has been characterized by a liberalization of foreign trade, which it has increased since the early $80 \mathrm{~s}$. This policy mainly aims at the integration of the Moroccan economy into the world economy and the contribution to the strengthening of the multilateral trading system.

Accordingly, Morocco has not only opted for the simplification of foreign trade procedures such as the reduction in tariff protection, the elimination of non-tariff measures, the improvements in business and investments environments to make them more secure but for the expansion and the diversification of economic and trade relationships as well.

The process of economic liberalization and integration into the global economy has been consolidated through a number of free trade agreements. So, the main trades agreements concluded by Morocco1, such as the association agreement with the European Union, the free trade agreement with the United States and Turkey, the European Association of Free Trade (EAFT)2, the regional free trade agreement (called Agadir agreement), the bilateral free trade agreement with Jordan, Tunisia and Egypt, the Greater Arab Free Trade Area (GAFTA) agreement, and the Preferential Trade Agreements (PTA) with Saudi Arabia, Algeria, Libya, Mauritania,
Republic of Guinea and Chad.

All these agreements constitute a big opportunity for Morocco to develop its exports and its imports mainly: agricultural products and textiles. They have also enabled Morocco to get advantage of the direct investments and to benefit from strong interior demand of these countries.

The relationship between export, import and economic growth (measured by Gross Domestic Product 'GDP') takes a central place in the literature on economic development and it is a question of major policy concern for government planners and policy makers. To this end, it is very interesting to know the direction of causality between these variables. The determination of this direction has important implications for trade policies.

There are several studies which have been conducted to investigate the relationship between export, import and economic growth. These studies used generally two types of empirical studies i.e. Cross-sectional studies, which determine the relationship between export, import and economic growth on group of countries, and cross-country time series studies, which individually investigate this relationship between among the variables on single country.

The theoretical and empirical investigation provides conflicting views in the nature of relationship between export and GDP or between import and GDP or between all these variables. This paper proposes an empirical investigation to determinate the nature of the relationship among these 
variables in the Moroccan context, i.e. the existence of this relationship is in the short-run and/or the long-run, and the determination of causality direction between these variables.

The importance of this paper stems from the following elements. Firstly, Morocco has opted for the liberalization of its economy by signing several agreements, partnerships and associations. So, it is very interesting to know the impact of the export and import on economic growth. Secondly, the majority previous researches related to this topic have examined the relationship between export, import and economic growth of other countries. Very few have examined this relationship in the Moroccan context. Thirdly, the determination of causality direction between among the variables can implant the best strategies of trade for the Moroccan economy, because the strategic direction is very important for the improvement of citizens living conditions through the reduction of poverty and the reduction of unemployment. I agree that the trade agreements signed by Morocco can offer the opportunities to reduce unemployment by the creation of new jobs and, also, to upgrade old jobs. Hence, the trade is one of the factors to reduce the unemployment rate (mainly the unemployment of young educated, which it is the bigger problem in Morocco).

The study plan is organized as follows. Section 2 presents a short literature review. Section 3 details the methodology used to examine the above-mentioned relationship. Section 4 provides and discusses the results. The last section contains conclusions and remarks.

\section{Literature Review}

The theoretical foundation of the relationship between trade openness and economic growth goes back to the founders of the classical theory. In fact, Smith and Ricardo were the first to identify the advantages that can be drawn by the countries to liberalize their trade.

Opposing to the mercantilists, Adam Smith (1776), "an inquiry into the nature and causes of the wealth of nations", argued that "it was impossible for all nations to become rich simultaneously by following mercantilism because the export of one nation is another nation's import and instead stated that all nations would gain simultaneously if they practiced free trade and specialized in accordance with their absolute advantage", Das Monica (2007).

According to Smith, countries are able to buy the products they need at a cheap price instead of producing them by themselves. Although trade is not necessary for development because the production is determined by the factor of capital; he admitted that the free exchange can develop the accumulation of capital. That was the foundation of the theory of absolute advantage which led to international specialization and international division of labour.

In the comparative advantage theory, Ricardo (1817), "on the principles of political economy and taxation", has shown that if the country was open then it can reorient its scarce resources towards more efficient sectors and to improve its wellbeing. In his theory, the trade is win-win situation as workers in all trading countries are able to consume more of all goods.

In the new world context, countries cannot live in autarchy. The import and the export are the main components of GDP. To its calculating, GDP -in the expenditures approach- is the sum of four categories of expenditures, such are: the private consumption expenditures by households (C), the gross private investment (I), the government expenditures $(\mathrm{G})$, and the net exports which equal at exports (Exp) minus imports (M). Here is an equation: $\mathrm{GDP}=\mathrm{C}+\mathrm{I}+\mathrm{G}+($ Exp-M $)$.

The upper equation raises a main issue for economists, which it is the determination of causality direction between export, import and economic growth. Several empirical studies find no conclusive evidences of this causality. These studies cover different countries developing and emerging economies including MENA. Following is a selection from such studies.

Michaely (1977) had tested, using the Spearman rank coefficient, if the rate of growth of exports was associated with GDP growth. He studied a sample of 41 countries for the period 1950-1973. He found that while the coefficient was significantly positive $(0.380)$ for the whole sample, it was larger (0.523), for a subsample of 23 middle income countries. Heller and Porter (1978) have tested the same date as Michaely (1977). They showed that "the growth of exports is related to the growth of nonexport components of output" and the coefficient of Spearman rank correlation is 0.452 , which is higher than Michaely's coefficient (0.380). These authors investigation like Michaely's, found out that this coefficient was 0.568 for the richer countries and 0.097 for the poorer countries. The results confirmed the links between these variables but they did not determine the nature of these links.

Balassa (1985 and 1988) had concluded that trade development positively influences economic growth, which a country can take advantage of scale economies, promote technical change, increase the resource allocation efficiency, and overall productivity.

Jung and Marshall (1985) had tested, using Granger-type causality tests, the causal directions between exports and economic growth on data for 37 developing countries for the period 1951-1981. They found out evidence of unidirectional exports-to-growth causality only for four countries (Indonesia, Egypt, Costa Rica, and Ecuador).

Ahmad and Kwan (1991) have analyzed, using Granger causality tests, relationship between exports and growth national income from a consistent data set for 47 developing countries in Africa. The tests were applied first to the full sample of 47 countries (including Morocco) over the sevenyear period 1981-87. Then, it was disaggregated into two subsets: the one comprising 30 low-income countries and the other comprising 17 high and middle income countries. This classification was done in order to test as to whether causality and its direction are liable to vary with the stage of development of countries as proxied by their per capita income. They concluded that "the causality inferences indicate no causal link from exports to economic growth, or 
vice versa. Some subsets of sample countries provide weak support for causation running from economic growth to exports".

Ramos (2001) investigates the Granger-causality between exports, imports, and economic growth in Portugal over the period 1865-1998. The results showed no kind of significant causality between the variables considered.

Din, M. (2004) examines the export-led-growth hypothesis for the five largest economies of the South Asian region using a multivariate time-series framework. The results indicate (i) bidirectional causality between exports and output growth in Bangladesh, India, and Sri Lanka in the short-run, (ii) the existence of long-run equilibrium relationships among exports, imports, and output for Bangladesh and Pakistan and (iii) no evidence of a long-run relationship among the variables for India, Nepal, and Sri Lanka.

Bouoiyour (2003) investigates the relationship between trade and economic growth in Morocco over the period 19602000 using the VEC model. The results show imports Granger caused exports and both imports and exports Granger caused GDP. This last result is also that reached by Demirhan and Akcay (2005). They found out that exports cause economic growth in Morocco and Jordon cited by Wadad (2012).

\section{Research Method}

\subsection{Data}

According to data of High Commissariat of Plan (HCP) of Morocco, the growth of the Moroccan economy recorded an average rate of $4.2 \%$ during the period $1980-2013$, see Table1.
It is lower than that realized by foreign trade. The real GDP recorded an average rate of 4.9\% during 1980-1989, 3.2\% during 1990-1999 and 4.4\% during 2000-2009. The higher rate was recorded in 2011 of $13.6 \%$. So the growth rate of export is more important than this of real GDP. During 20002009 , the growth rate of import is more important than the growth rate of GDP and the growth rate of export, see Table 1.

Table 1. Growth rate of GDP (RGDP\%), Exports (Rex\%) and Imports $(R M \%)$.

\begin{tabular}{lllll}
\hline & $\mathbf{1 9 8 0 - 1 9 8 9}$ & $\mathbf{1 9 9 0 - 1 9 9 9}$ & $\mathbf{2 0 0 0 - 2 0 0 9}$ & $\mathbf{1 9 8 0 - 2 0 1 3}$ \\
\hline RGDP $\%$ & $4.9 \%$ & $3.2 \%$ & $4.4 \%$ & $4.2 \%$ \\
REx $\%$ & $5.9 \%$ & $6.5 \%$ & $5.6 \%$ & $6.0 \%$ \\
RM $\%$ & $3.7 \%$ & $5.2 \%$ & $7.1 \%$ & $5.0 \%$ \\
\hline
\end{tabular}

Source: Calculated according to data of HCP (2015)

The analysis of the trade balance shows that Morocco records a deficit important since 1980 and it is worsened these last six years (Figure1). The average annual rate of the imports increased, respectively, from $4.6 \%$ to $5.6 \%$ between 1980-2000 and 2001-2013. Although, the average annual rate of the exports decreased of $6.3 \%$ in $1980-2000$ to $5.4 \%$ in 2001-2013.

In 2009, the real export of Morocco recorded a negative rate $(-8 \%)$; likewise the rate of world exports recorded ($12 \%)^{3}$. This trough is the consequence of the crisis 2008 .

The Figurel depicts that the evolution of import and export follows the same tendency. The rate of coverage has increased since 1980s; recording a higher rate in 2001 of $101 \%$. The average growth of this rate decreases from $92.7 \%$ to $83.8 \%$ during $2001-2008$ and $2009-2013$.

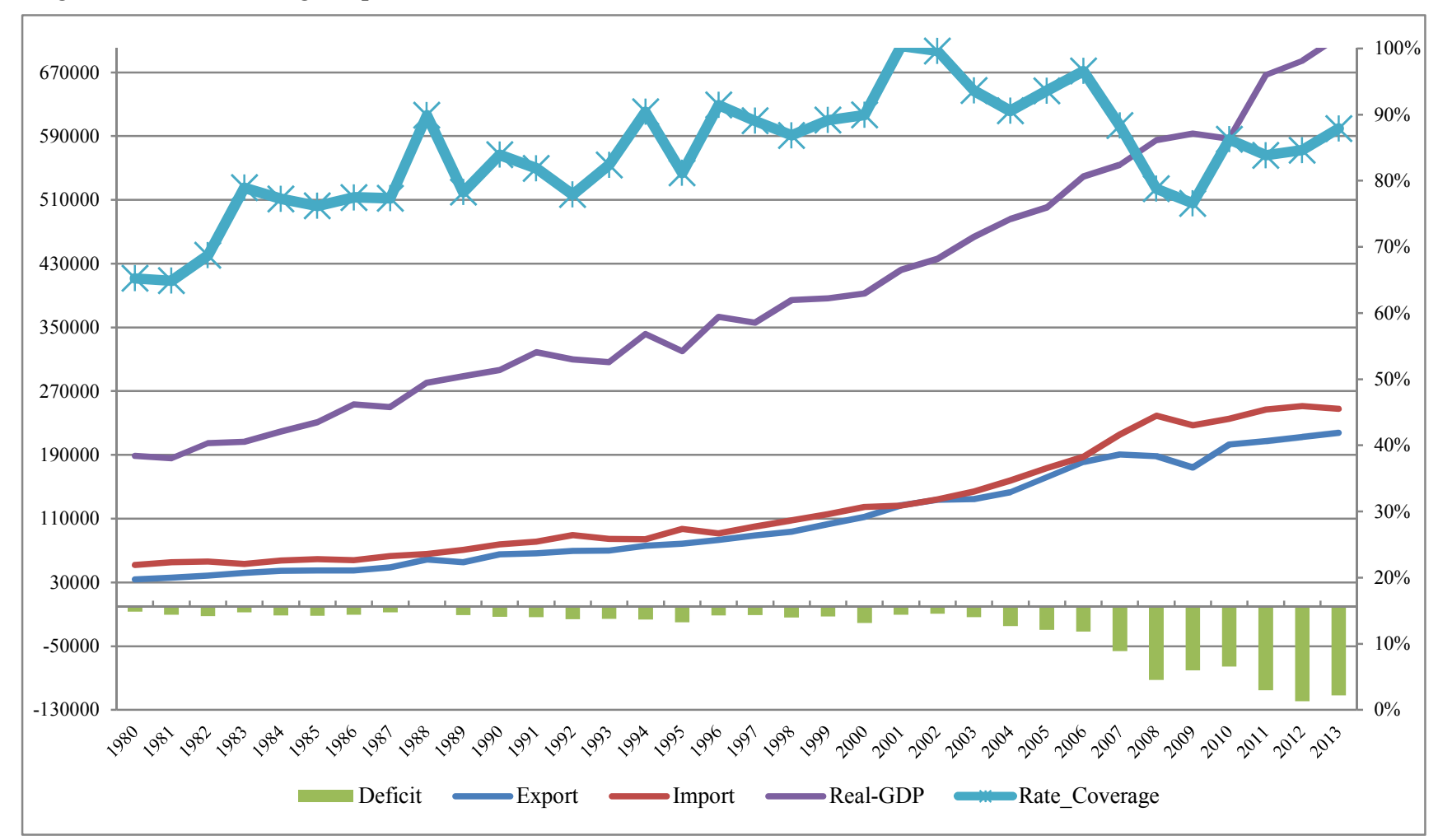

Figure 1. Evolution of export, import, GDP, deficit and rate of coverage during 1980-2013. 


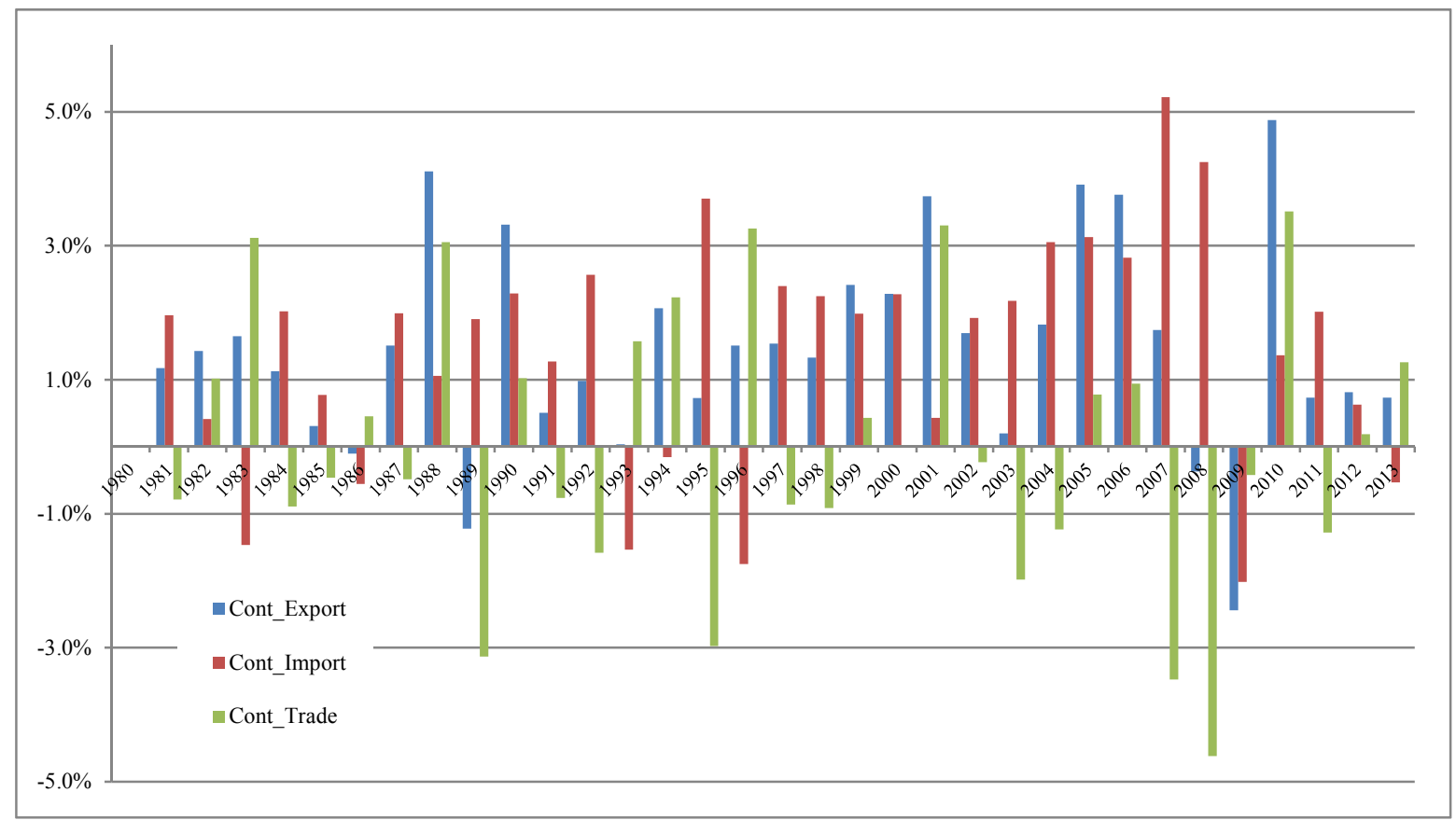

Figure 2. Contribution of Export and Import at GDP, in \%, during 1980-2013.

The contribution of exports in GDP is very feeble than that imports during the period 1980-2013 (Figure 2). This situation explains the negative contribution of trade in GDP, recording an average rate of $-0.2 \%$ during the period 2000 2013. The lower rate is recorded in $2008(-4.6 \%)$.

An other characteristic of Moroccan trade is the dominance of trade with EU-28. These countries present $60 \%$ in the Moroccan trade 4. Both imports and exports have increased with average rate of $8.2 \%$ and of $5.2 \%$, respectively,

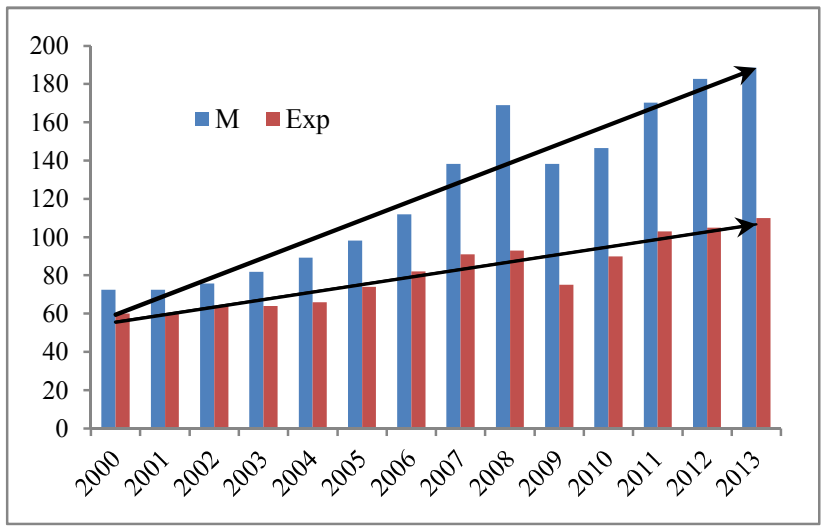

Figure 3. Evolution of Moroccan trade with EU-28 during 2000-2013 (in Billions of Dhs).

Over the period 2000-2013, the Moroccan exports and Imports has noticed an upward trend for partners outside EU28:

- The exports recorded an average annual growth rate of $14 \%$ for the United States, $15 \%$ for EFTA, $22 \%$ for Turkey, $10 \%$ for the Quad, and 36\% for United Arab Emirates (UAE) against only 5\% for the EU-28;

- The imports recorded an average annual growth rate of during the period 2000-2013. This evolution records a decrease of $-18.2 \%$ for imports and $-19.4 \%$ for exports in 2009.

After the signing of the free trade agreement (FTA), Moroccan trade with EU-28 has an increasing trend, as shown in Figure 3. However, this dominance has relatively changed after signing of free trade agreement (FTA) with countries outside European countries. This situation is reported in Figure 4.

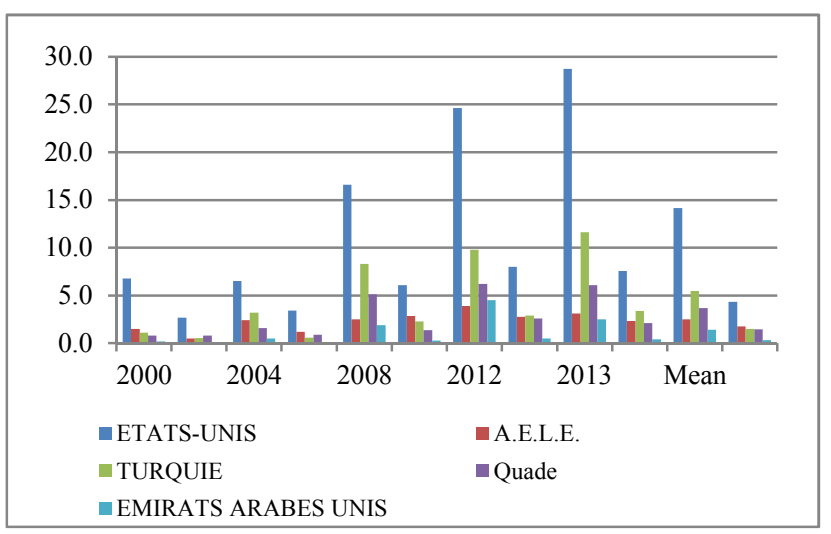

Figure 4. Evolution of Moroccan trade outside EU-28 during 2000-2013 (in Billions of Dhs).

$14 \%$ from the United States, $6 \%$ from EFTA, 21\% from Turkey, $18 \%$ from the Quad, and $31 \%$ from UAE against only $8 \%$ from the EU-28.

\subsection{Econometric Methodology}

The VECM is used to analyse the relationship between export, import and economic growth. This model involves the following important steps. The first step studies the 
stationarity of these variables using the ADF test5. If the variables are non-stationary and integrated of the same ordered. Then, it is possible to move to the second step. This step checks the existence of a long-term stable relationship among these variables. There are several tests for cointegration. The Johansen's test 6 has been used as primary statistical tools in the analyses which it is considered as a superior and a popular test in agreement with many studies.

The last step depends on the results of the Johansen's test. If there is a relation of cointegration between the dependent variable and the explanatory variables, then it is able to deduct the existence of a long-term dynamic relation between these variables. But, if these variables are not cointegrated, then it is able to deduct the non-existence of a long-run relationship. In this case, it is possible the existence that there is only a short-run relationship between these variables. To complete the analysis of this study, it is important to study the sense of their causality with the Granger test7.

According to many studies see Din (2004), Afzal (2006), Saad (2012) and Abbas (2012), our model is written according to the following three systems. All variables are used in real term and transformed in logarithmic: $\mathrm{LY}_{\mathrm{t}}=\log \left(\mathrm{Y}_{\mathrm{t}}\right)$.

System 1:

The long-run equation:

$$
L R G D P_{t}=a_{0}+a_{1} L R E x_{t}+a_{2} L R M_{t}+\varepsilon_{0 t}
$$

The short-run equation:

$$
\begin{gathered}
\Delta L R G D P_{t}=\alpha_{0}+\sum_{i=1}^{p} \alpha_{1 i} \Delta L R G D P_{t-i}+\sum_{i=1}^{p} \alpha_{2 i} L R E x_{t-i}+\sum_{i=1}^{p} \alpha_{3 i} L R M_{t-i}+\alpha_{4} E C M_{t-1}+\varepsilon_{1 t} \\
\Delta L R E x_{t}=\beta_{0}+\sum_{i=1}^{p} \beta_{1 i} \Delta L R E x_{t-i}+\sum_{i=1}^{p} \beta_{2 i} L R G D P_{t-i}+\sum_{i=1}^{p} \beta_{3 i} L R M_{t-i}+\beta_{4} E C M_{t-1}+\varepsilon_{2 t} \\
\Delta L R M_{t}=\mu_{0}+\sum_{i=1}^{p} \mu_{1 i} \Delta L R M_{t-i}+\sum_{i=1}^{p} \mu_{2 j} L R G D P_{t-i}+\sum_{i=1}^{p} \mu_{3 i} L R E x_{t-i}+\mu_{4} E C M_{t-1}+\varepsilon_{3 t}
\end{gathered}
$$

System 2:

The long-run equation:

$$
L R G D P_{t}=b_{0}+b_{1} L R E x_{t}+v_{0 t}
$$

The short-run equation:

$$
\begin{gathered}
\Delta L R G D P_{t}=\lambda_{0}+\sum_{i=1}^{q} \lambda_{1 i} \Delta L R G D P_{t-i}+\sum_{i=1}^{q} \lambda_{2 i} L R E x_{t-i}+\lambda_{3} E C M_{t-1}+v_{1 t} \\
\Delta L R E x_{t}=\varphi_{0}+\sum_{i=1}^{q} \varphi_{1 i} \Delta L R E x_{t-i}+\sum_{i=1}^{q} \varphi_{2 i} L R G D P_{t-i}+\varphi_{3} E C M_{t-1}+v_{2 t}
\end{gathered}
$$

System 3:

The long-run equation:

$$
L R G D P_{t}=c_{0}+c_{1} L R M_{t}+\xi_{0 t}
$$

The short-run equation:

$$
\begin{gathered}
\Delta L R G D P_{t}=\psi_{0}+\sum_{i=1}^{m} \psi_{1 i} \Delta L R G D P_{t-i}+\sum_{i=1}^{m} \psi_{2 i} L R M_{t-i}+\psi_{3} E C M_{t-1}+\xi_{1 t} \\
\Delta L R M_{t}=\kappa_{0}+\sum_{i=1}^{m} \kappa_{1 i} \Delta L R M_{t-i}+\sum_{i=1}^{m} \kappa_{2 i} L R G D P_{t-i}+\kappa_{3} E C M_{t-1}+\xi_{2 t}
\end{gathered}
$$

Where, $\Delta$ represents the difference operator. The symbols of $\mathrm{p}, \mathrm{q}$ and $\mathrm{m}$ are the number of lags. The signs of $\varepsilon(\mathrm{i}=0,1,2$, $3), v(i=0,1,2)$, and $\xi(i=0,1,2)$ present the stochastic error term with mean zero and a constant variance. $\mathrm{ECM}_{\mathrm{t}-1}$ referred to the error correction term derived from the long-run relationship.

In the case where variables are stationary $\mathrm{I}(0)$, the equations without the ECM can be estimated using the least squares method. However, if the variables are non-stationary I(d) and are not cointegrated, the Vector autoregression (VAR) model 8 in the $\mathrm{d}^{\text {th }}$ difference form and without the ECM can be used and estimated.

\section{Results and Discussion}

\subsection{Unit Root Test}

According to data of HCP of Morocco, the annual time series data from 1980 to 2013 is used. In the first step, stationary of the variables (import, export and GDP) has been 
investigated by the ADF test. Table 2 summarizes the results.

Table 2. Stochastic properties of variables, annually series.

\begin{tabular}{llllll}
\hline \multirow{2}{*}{ Variables } & Variables in level & & \multicolumn{2}{l}{ Variables in first difference } \\
\cline { 2 - 5 } & $\begin{array}{l}\text { ADF statistic include } \\
\text { intercept }\end{array}$ & $\begin{array}{l}\text { Critical values of the ADF } \\
\text { statistic }\end{array}$ & ADF statistic & $\begin{array}{l}\text { Critical values of the ADF } \\
\text { statistic }\end{array}$ & Conclusion \\
\hline LRGDP & $-0,5085$ & $-2,9571$ & $-13,0288$ & $-2,9571$ & $\mathrm{I}(1)+\mathrm{C}$ \\
LRM & 0,1635 & $-2,9540$ & $-5,9093$ & $-2,9571$ & $\mathrm{I}(1)+\mathrm{C}$ \\
LREx & $-0,8132$ & $-2,9540$ & $-7,0495$ & $-2,9571$ & $\mathrm{I}(1)+\mathrm{C}$ \\
\hline
\end{tabular}

Notes: The critical value is at $5 \%$ level. $\mathrm{C}$ and/or T indicate that the ADF test is conducted with a constant and/or a trend.

From the upper panel of results, all variables are stationary in the first difference: LRGDP, LRM and LREx are integrated of order one I(1). This result suggests a stable long-run relationship between these variables.

\subsection{Johansen Cointegration Test}

To ensure proper specification of our model, it is necessary to determine the optimum lags lengths (p), which are determined using five criterions: the sequential modified LR test, the Final prediction error (FPE), the Akaike information criterion (AIC), the Schwarz information criterion (SC), and the Hannan-Quinn information criterion (HQ).

For system 1, these criterions don't give the same lengths (Table 3). The SC suggests lags are $p=1$, and the other criterions suggest lags are $p=4$. However, the results of the estimation of model led us to adopt four (4) lags on level. Therefore, the Johansen test was made on stationary series with three (3) lags.

Table 3. Determination of optimum lags lengths (p) for system 1.

\begin{tabular}{lllllll}
\hline \multicolumn{2}{l}{ Endogenous variables: LRGDP, LREx and LRM } \\
\hline Lags & LogL & LR & FPE & AIC & SC & HQ \\
\hline 0 & 69.72117 & NA & $2.87 \mathrm{e}-06$ & -4.248078 & -3.967839 & -4.158427 \\
1 & 170.8466 & 168.5425 & $6.23 \mathrm{e}-09$ & -10.38978 & $-9.689178^{*}$ & -10.16565 \\
2 & 182.3317 & 16.84471 & $5.44 \mathrm{e}-09$ & -10.55545 & -9.434487 & -10.19684 \\
3 & 192.9871 & 13.49682 & $5.21 \mathrm{e}-09$ & -10.66580 & -9.124487 & -10.17272 \\
4 & 212.5607 & $20.87851^{*}$ & $2.93 \mathrm{e}-09^{*}$ & $-11.37071^{*}$ & -9.409035 & $-10.74315^{*}$ \\
\hline
\end{tabular}

Notes:* indicates lag order selected by the criterion at $5 \%$ level.

For system 2 , the criterions tests give the same lengths $\mathrm{p}=2$ (Table 4 ). So, the Johansen test was made on stationary series with 1 lag.

Table 4. Determination of optimum lags lengths (p) for system 2.

\begin{tabular}{lllllll}
\hline \multicolumn{6}{l}{ Endogenous variables: LRGDP and LREx } \\
\hline Lags & LogL & LR & FPE & AIC & SC & HQ \\
\hline 0 & 27.35443 & NA & 0.000723 & -1.556962 & -1.370136 & -1.497195 \\
1 & 108.0446 & 139.8630 & $4.36 \mathrm{e}-06$ & -6.669642 & -6.295989 & -6.550107 \\
2 & 118.7178 & $17.07700^{*}$ & $2.82 \mathrm{e}-06^{*}$ & $-7.114517^{*}$ & $-6.554038^{*}$ & $-6.935215^{*}$ \\
3 & 119.5200 & 1.176705 & $3.54 \mathrm{e}-06$ & -6.901337 & -6.154031 & -6.662267 \\
4 & 125.0983 & 7.437604 & $3.27 \mathrm{e}-06$ & -7.006550 & -6.072419 & -6.707713 \\
\hline
\end{tabular}

For system 3, the results of all criterions give the same lengths $\mathrm{p}=4$ (Table 5). Therefore, the Johansen test was made on stationary series with three (3) lags.

Table 5. Determination of optimum lags lengths (p) for system 3.

\begin{tabular}{|c|c|c|c|c|c|c|}
\hline \multicolumn{7}{|c|}{ Endogenous variables: LRGDP and LRM } \\
\hline Lags & $\log L$ & LR & FPE & AIC & SC & HQ \\
\hline 0 & 28.20158 & NA & 0.000646 & -1.669075 & -1.480482 & -1.610010 \\
\hline 2 & 122.9123 & 21.49083 & $1.65 \mathrm{e}-06$ & -7.649128 & -7.083350 & -7.471933 \\
\hline 3 & 125.6800 & 4.008385 & $1.83 \mathrm{e}-06$ & -7.564141 & -6.809771 & -7.327882 \\
\hline 4 & 140.2443 & $19.08419^{*}$ & $9.10 \mathrm{e}-07 *$ & $-8.292710^{*}$ & $-7.349747 *$ & $-7.997386^{*}$ \\
\hline
\end{tabular}


The results of the Johansen test imply that a long-run association exists among LRGDP, LREx and LRM. These results are reported in Table 6.

Table 6. Results of the Johansen Cointegration Test.

\begin{tabular}{|c|c|c|c|c|c|c|c|}
\hline \multicolumn{2}{|c|}{ System 1} & \multicolumn{3}{|l|}{ Max-Eigen } & \multicolumn{3}{|l|}{ Trace } \\
\hline HO & Eigenvalue & Statistic & $C V * *$ at $5 \%$ & Prob.*** & Statistic & CV at $5 \%$ & Prob. \\
\hline$*_{r}=0$ & 0.509051 & 21.34245 & 21.13162 & 0.0467 & 34.21975 & 29.79707 & 0.0145 \\
\hline $\mathrm{r}=1$ & 0.348998 & 12.87730 & 14.26460 & 0.0818 & 12.87730 & 15.49471 & 0.1194 \\
\hline $\mathrm{r}=2$ & 4.48E-08 & $1.34 \mathrm{E}-06$ & 3.841466 & 0.9996 & $1.34 \mathrm{E}-06$ & 3.841466 & 0.9996 \\
\hline \multicolumn{8}{|c|}{ System 2} \\
\hline $\mathrm{r}=0$ & 0.723817 & 41.17409 & 15.89210 & 0.0000 & 48.09142 & 20.26184 & 0.0000 \\
\hline $\mathrm{r}=1$ & 0.194399 & 6.917324 & 9.164546 & 0.1308 & 6.917324 & 9.164546 & 0.1308 \\
\hline \\
\hline $\mathrm{r}=0$ & 0.494014 & 20.43741 & 15.89210 & 0.0225 & 22.71847 & 20.26184 & 0.0090 \\
\hline $\mathrm{r}=1$ & 0.073217 & 2.281060 & 9.164546 & 0.7214 & 2.281060 & 9.164546 & 0.7214 \\
\hline
\end{tabular}

Notes: *r is the number of the hypothesized cointegrating relationships, and **MacKinnon-Haug-Michelis (1999) p-values.

All results provide the existence a long-run relationship between variables. The long-run estimated coefficients are reported in Table 7.

Table 7. Cointegrating vectors between the variables of the three systems.

\begin{tabular}{llll}
\hline & System1 & System 2 & System 3 \\
\cline { 2 - 4 } & LRGDP $_{\mathbf{t}}$ & LRGDP $_{\mathbf{t}}$ & LRGDP $_{\mathbf{t}}$ \\
\hline Constant & 4.0180 & $6.3267(8.3650)$ & $3.6852(5.6787)$ \\
LREx $_{\mathrm{t}}$ & $0.7192(1.9643)$ & $0.6125(9.2751)$ & ---- \\
LRM $_{\mathrm{t}}$ & $0.0497(0.1274)$ & ---- & $0.8211(14.4830)$ \\
\hline
\end{tabular}

Notes: In parentheses are the t-statistics.

The statistically significant positive long-run coefficients of LREx and LRM indicate that exports and imports have positive effects on economic growth.
The VECM will be employed as well to complete the investigation for each system. This model is validated if the coefficient attached to this residual (ECM) is negative (between -1 and 0 ), and it is statistically significant. The results are presented in Table 8.

The coefficients attached to the $\mathrm{ECM}_{\mathrm{t}-1}$ of equation (1.2), equation (2.2) and equation (3.2) are negative and they are statistically significant at 5\%. At long term, both export and import correct $18.4 \%$ of real GDP (equation (1.2)), and real export corrects $12.7 \%$ of real GDP (equation (2.2)) and real import corrects $14.1 \%$ of real GDP (equation (3.2)). Therefore, these results show that, in long-run relationship, one way directional causality exists between export, import and GDP: (i) from export and import to economic growth, (ii) from export to economic growth, and (iii) from import to economic growth.

Table 8. Results of the simulated VECM.

\begin{tabular}{|c|c|c|c|c|c|c|c|}
\hline & \multicolumn{3}{|l|}{ System1 } & \multicolumn{2}{|l|}{ System 2} & \multicolumn{2}{|l|}{ System 3} \\
\hline & $\begin{array}{l}\text { D(LRGDP) } \\
(1.2) \\
\end{array}$ & $\begin{array}{l}\text { D(LREx) } \\
(\text { S1.3) } \\
\end{array}$ & $\begin{array}{l}\text { D(LRM) } \\
\text { (S1.4) } \\
\end{array}$ & $\begin{array}{l}\text { D(LRGDP) } \\
(2.2) \\
\end{array}$ & $\begin{array}{l}\text { D(LREx) } \\
(2.3) \\
\end{array}$ & $\begin{array}{l}\text { D(LRGDP) } \\
(3.2) \\
\end{array}$ & $\begin{array}{l}\text { D(LRM) } \\
(3.3) \\
\end{array}$ \\
\hline \multirow{3}{*}{$\mathrm{ECM}_{\mathrm{t}-1}$} & -0.183942 & -0.133544 & -0.003032 & -0.127405 & 0.096145 & -0.140357 & -0.059627 \\
\hline & $(0.07865)$ & $(0.10141)$ & $(0.00433)$ & $(0.01612)$ & $(0.01703)$ & $(0.04783)$ & $(0.04315)$ \\
\hline & {$[-2.33883]$} & {$[-1.31693]$} & {$[-0.70084]$} & {$[-7.90559]$} & [ 5.64609] & {$[-2.93446]$} & [-1.38186] \\
\hline \multirow{3}{*}{$\mathrm{D}_{\left(\mathrm{LRGDP}_{-1}\right)}$} & -0.758943 & -0.012572 & 1.128112 & -0.697881 & 0.041839 & -0.627733 & 1.225283 \\
\hline & $(0.18185)$ & $(0.32601)$ & $(0.20141)$ & $(0.11614)$ & $(0.20035)$ & $(0.15467)$ & $(0.16993)$ \\
\hline & {$[-4.17355]$} & {$[-0.03856]$} & [ 5.60117] & {$[-6.00871]$} & [ 0.20883] & {$[-4.05856]$} & [ 7.21055] \\
\hline \multirow{3}{*}{$\mathrm{D}\left(\mathrm{LRGDP}_{-2}\right)$} & 0.380297 & 0.437545 & 0.446642 & & & 0.299411 & 0.407518 \\
\hline & $(0.23997)$ & $(0.43021)$ & $(0.26578)$ & & & $(0.21056)$ & $(0.23133)$ \\
\hline & [ 1.58477$]$ & [ 1.01705$]$ & [ 1.68048$]$ & & & [ 1.42198$]$ & {$[1.76160]$} \\
\hline \multirow{3}{*}{ D(LRGDP -3$)$} & 0.505969 & 0.079053 & -0.152690 & & & 0.392786 & -0.114829 \\
\hline & $(0.20362)$ & $(0.36504)$ & $(0.22552)$ & & & $(0.18629)$ & $(0.20467)$ \\
\hline & [ 2.48490$]$ & {$[0.21656]$} & {$[-0.67706]$} & & & [ 2.10852] & {$[-0.56106]$} \\
\hline \multirow{3}{*}{$\mathrm{D}\left(\mathrm{LREx}_{-1}\right)$} & 0.040383 & -0.114516 & 0.315255 & 0.023773 & -0.279355 & & \\
\hline & $(0.10587)$ & $(0.18981)$ & $(0.11726)$ & $(0.09209)$ & $(0.15886)$ & & \\
\hline & [ 0.38143$]$ & {$[-0.60333]$} & [ 2.68846] & [ 0.25814$]$ & {$[-1.75848]$} & & \\
\hline
\end{tabular}




\begin{tabular}{|c|c|c|c|c|c|c|c|}
\hline & \multicolumn{3}{|l|}{ System1 } & \multicolumn{2}{|l|}{ System 2} & \multicolumn{2}{|l|}{ System 3} \\
\hline & $\begin{array}{l}\text { D(LRGDP) } \\
(1.2)\end{array}$ & $\begin{array}{l}\text { D(LREx) } \\
\text { (S1.3) }\end{array}$ & $\begin{array}{l}\text { D(LRM) } \\
\text { (S1.4) }\end{array}$ & $\begin{array}{l}\text { D(LRGDP) } \\
(2.2)\end{array}$ & $\begin{array}{l}\text { D(LREx) } \\
\text { (2.3) }\end{array}$ & $\begin{array}{l}\text { D(LRGDP) } \\
(3.2)\end{array}$ & $\begin{array}{l}\text { D(LRM) } \\
\text { (3.3) }\end{array}$ \\
\hline \multirow{3}{*}{ D(LREx.-2) } & 0.063790 & -0.204713 & 0.108052 & & & & \\
\hline & $(0.11717)$ & $(0.21005)$ & $(0.12977)$ & & & & \\
\hline & [0.54443] & {$[-0.97457]$} & [ 0.83263$]$ & & & & \\
\hline \multirow{3}{*}{ D(LREx-3) } & -0.022160 & -0.320908 & -0.066180 & & & & \\
\hline & $(0.09942)$ & $(0.17823)$ & $(0.11011)$ & & & & \\
\hline & {$[-0.22290]$} & {$[-1.80048]$} & {$[-0.60102]$} & & & & \\
\hline \multirow{3}{*}{$\mathrm{D}\left(\mathrm{LRM}_{-1}\right)$} & -0.299083 & 0.003958 & 0.079692 & & & -0.164810 & 0.213234 \\
\hline & $(0.14274)$ & $(0.25590)$ & $(0.15809)$ & & & $(0.12346)$ & $(0.13564)$ \\
\hline & {$[-2.09532]$} & [0.01547] & [ 0.50408] & & & {$[-1.33493]$} & [ 1.57205$]$ \\
\hline \multirow{3}{*}{$\mathrm{D}\left(\mathrm{LRM}_{-2}\right)$} & -0.150365 & 0.426962 & 0.144566 & & & -0.108577 & 0.071968 \\
\hline & $(0.13340)$ & $(0.23915)$ & $(0.14775)$ & & & $(0.12155)$ & $(0.13355)$ \\
\hline & {$[-1.12719]$} & [ 1.78532$]$ & [ 0.97847$]$ & & & {$[-0.89325]$} & [ 0.53890$]$ \\
\hline \multirow{3}{*}{$\mathrm{D}\left(\mathrm{LRM}_{-3}\right)$} & -0.144005 & -0.005753 & 0.186713 & & & -0.143680 & 0.206323 \\
\hline & $(0.12148)$ & $(0.21778)$ & $(0.13454)$ & & & $(0.12163)$ & $(0.13363)$ \\
\hline & [-1.18545] & {$[-0.02642]$} & [ 1.38775$]$ & & & [-1.18133] & [ 1.54403$]$ \\
\hline \multirow{3}{*}{$\mathrm{C}$} & 0.055424 & 0.063173 & -0.039051 & & & & \\
\hline & $(0.02331)$ & $(0.04179)$ & $(0.02582)$ & & & & \\
\hline & [ 2.37741$]$ & [ 1.51153$]$ & {$[-1.51242]$} & & & & \\
\hline
\end{tabular}

Notes: $\mathrm{D}(.$.$) indicates the first difference of the variable: \mathrm{D}(\mathrm{Y})=\mathrm{Y}-\mathrm{Y}-1$,Standard errors in ( ) and the t-statistics are in [ ]. The results are obtained by using Eviews 5.

Beside these long-run relationships between these variables, the short-run relationship between these three variables is tested using Granger causality test. This test is done to see the short-run causality running from independent variable to dependent variable, which the null hypothesis is the lagged values of coefficients in each equation are zero. If the $\mathrm{P}$-value is less than $5 \%$, then the null hypothesis (H0) is rejected. Meaning that, the independent variables jointly can influence dependant variable. The results are presented in Table 9.

Table 9. Granger Causality-Wald statistics.

\begin{tabular}{llll}
\hline & D(LRGDP) & D(LREx) & D(LRM) \\
\hline $\mathrm{D}($ LRGDP $)$ & --- & $1.8382(0.6067)$ & $32.5519(0.0000)$ \\
$\mathrm{D}($ LREx $)$ & $0.5487^{*}(0.9081)^{* *}$ & --- & $8.2811(0.0405)$ \\
$\mathrm{D}($ LRM $)$ & $6.3748(0.0947)^{* * *}$ & $3.3985(0.3342)$ & --- \\
\hline
\end{tabular}

Notes: $*$ presents the $\chi^{2}$ statistics. ${ }^{* *}$ presents the probability. ${ }^{* * *}$ Import can influence RGDP at $10 \%$.

In short-run relationship, the findings suggest (i) bidirectional causality between economic growth and import, (ii) unidirectional causality that run from export to import and (iii) no-directional causality between economic growth and export.

\section{Conclusion}

The aim for this study is twofold. First, analyse the relationship between export, import and GDP in the particular context of Morocco. Second, if such a relationship exists, find the direction of causality in long-run and shortrun. To attain these objectives, this article has attempted to test empirically the cointegration between these variables.

Several interesting results have been finding. First, export and import enter with positive signs in the cointegration equation. Second, one way direction causality exist in longrun between these variables that run (i) from export and import to economic growth, (ii) from export to economic growth and (iii) from import to economic growth. Third, the results of the Granger causality test show that in short-run relationship there exists (i) bidirectional causality between economic growth and import, (ii) unidirectional causality that run from export to import and (iii) no-directional causality between economic growth and export.

It is surprising that there is no-causality between export and economic growth in short-run. This can be referred to the fact that the Moroccan economy depends in the condition climatic mainly in short-run. The agriculture sector represents between $12 \%$ and $17 \%$ of GDP between 2000 and 2013, and employs nearly $45 \%$ of the total workforce. However, the presence of long-run link between export and economic growth will has implications of great consequence on the development strategies of Morocco. Consequently, export and/or import will have importance in fuelling economic growth in long term. 


\section{References}

[1] ABBAS, S. (2012), Causality between Exports and Economic Growth: Investigating Suitable Trade Policy for Pakistan, Eurasian Journal of Business and Economics 2012, 5 (10), 9198

[2] Afzal, M. (2006), Causality between exports, world income and economic growth in Pakistan, International Economic Journal, 20(1), 63-77.

[3] Ahmad, J. and Kwan, A.C.C., (1991), Causality between exports and economic growth: Empirical evidence from Africa, Economics Letters (Vol. 37), 243-48.

[4] Balassa, B., (1985), Exports, Policy Choices, and Economic Growth in developing Countries After the 1973 oil Shock, Journal of Development Economics(18), 23-35.

[5] Balassa, B.,(1988), The lessons of the Asian development: an overview, Economic Development and Cultural Change, vol. 36 (3rd supplement).

[6] Bouiyour, J. (2003), Trade and GDP Growth in Morocco: Short-run or long-run causality?, Revista Brasileira de Economia de Empresas, Brasilia V.3 N.2, 19-26.

[7] Das, M. (2007), Absolute and Comparative Advantage, International Encyclopedia of the Social Sciences 2ND Edition.http://www.skidmore.edu/ mdas/AbsoluteandCompar ativeAdvantage.pdf

[8] Department of Studies and Financial Forecast of Ministry of Economy and Finance, Morocco, (2008), Foreign Trade Policy in Morocco: A Broad Assessment, http://www.finances.gov.ma/

Docs/2008/depf/4385_foreigntradepolicy_2.pdf

[9] Demirhan, E., and Akcay, S. (2005), The causality relationship between export growth and economic growth: Empirical evidence from selected MENA countries, Iktisat Isletmeve Finans, 20(230), 124-31.

[10] Dickey, D.A., and Fuller, W.A., (1979), Distributions of the estimators for autoregressive time series with a unit root, Journal of the American Statistical Association (74), 427-31.

[11] Dickey, D.A. and Fuller, W.A. (1981), Likelihood Ratio Statistics for Autoregressive Time Series with a Unit Root, Econometrica (Vol. 49), 1057-1072.

[12] Din, M. (2004), Exports, imports, and economic growth in South Asia: Evidence using a multivariate time-series framework, Pakistan Development Review, 43(2), 105-24.

[13] Elliot, G., Rothenberg, T.J., and Stock, J.H., (1996), Efficient tests for an autoregressive unit root, Econometrica (64), 813836.

[14] Granger, C.W.J., (1969), Investigating Causal Relations by Econometric and Cross-Spectral Method, Econometrica, Vol. 37, No. 3, 424-438.

[15] Granger, C.W.J.,(1986), Development in the Study of Cointegrated Economic Variables, Oxford Bulletin of Economics and Statistics (Vol. 48), 213-228.

[16] Heller, P.S., and Porter, R.C., (1978), Exports and growth: An empirical re-investigation, Journal of Development Economics 5: 191-193.
[17] Johansen, S., (1988), Statistical Analysis of Cointegration Vectors, Journal of Economic Dynamics and Control, Vol. 12, No. 2-3, 231-254.

[18] Johansen, S., and Juselius, K., (1990), Maximum Likelihood Estimation and Inference on Cointegration-with Applications to the Demand for Money, Oxford Bulletin of Economics and Statistics, Vol. 52, No. 2, 169-210.

[19] Jung, W.S. and Marshall, P.J., (1985), Exports, growth and causality in developing countries, Journal of Development Economics 18: 1-12.

[20] Kwiatkowski, D., Phillips, P.C.B., Schmidt, P., and Shin, Y., (1992), Testing the null hypothesis of stationarity against the alternative of a unit root: How sure are we that economic time series have a unit root?, Journal of Econometrics, 54, 15978.Lewis, C.D., (1982) Industrial and Business Forecasting Methods, Butterworths, London.

[21] Michaely, M., (1977), Exports and Growth, Journal of Development Economics 4, no.1 (March) 49-53

[22] Ng, S. and Perron, P., (2001). Lag Length Selection and the Construction of Unit Root Tests with Good Size and Power, Econometrica, Vol. 69, $\mathrm{N}^{\circ}$ 6, 1519-54.

[23] Phillips, P.C.B., and Perron, P., (1988), Testing for a unit root in time series regression, Biometrica, 75, 335-346.

[24] Ramos, F. F. R. (2001). Exports, imports, and economic growth in Portugal: evidence from causality and cointegration analysis. Economic Modelling, 18, 613-623.

[25] Report of Ministry of Foreign Trade, Morocco (2014), Analyse chiffrée du commerce extérieur marocain (20002013), www.mce.gov.ma

[26] Saad. W. (2012), Causality between Economic Growth, Export, and External Debt Servicing: The Case of Lebanon, International Journal of Economics and Finance; Vol. 4, No.11, 134-143.

1 For more information and further details, see website of Foreign Exchange Department of Ministry of Industry, Trade and New Technologies, Morocco. www.maroc-trade.gov.ma

2 There are four members: States-Iceland, Liechtenstein, Norway and Switzerland. 3 The percentage pulls to report of Ministry of Foreign Trade, Morocco (2014).

4 For more information, see report of Department of Studies and Financial Forecast of Ministry of Economy and Finance, Morocco (2008).

5 For more explication, see Dickey and Fuller $(1979,1981)$. There is other test to study the stationarity, such as: the Phillips-Perron test (PP, 1988), the Kwiatkowski-Phillip-Schmidt-Shin test (KPSS, 1992), the modified DickeyFuller test based on generalized least squares (DFGLS), the Elliot, Rottenberg and Stock (1996) point optimal test (ESROP), and the Ng-Perron test (NP, 2001).

6 For more detail and explication, see Johansen (1988), and Johansen and Juselius (1990).

7For more explication, see Granger $(1969,1986)$.

$8 \mathrm{VAR}$ is an econometric model used to capture the linear interdependencies among multiple time series. VAR models generalize the univariate autoregression (AR) models by allowing for more than one evolving variable. 